\title{
Analisis Determinan Pengungkapan Corporate Social Responsibility: Studi pada Perusahaan Indeks LQ45
}

\author{
Ni Made Dwitarini ${ }^{1}$ \\ Fakultas Ekonomi dan Bisnis \\ Universitas Udayana, Indonesia
}

\author{
Maria Mediatrix Ratna Sari ${ }^{2}$ \\ Fakultas Ekonomi dan Bisnis \\ Universitas Udayana, Indonesia
}

\begin{abstract}
Surel : nmddwitarini@gmail.com
ABSTRAK

Perusahaan hendaknya memperhatikan pelaksanaan Corporate Social Responsibility (CSR). Perusahaan publik diwajibkan menyusun laporan keberlanjutan, namun pengungkapannya bersifat sukarela, yang menyebabkan aspek yang dilaporkan setiap perusahaan berbeda. Perbedaan ini diduga disebabkan oleh beberapa faktor. Adapun tujuan penelitian untuk menguji faktor yang diduga berpengaruh terhadap pengungkapan CSR, Adapun faktor yang dimaksud yakni profitabilitas, leverage, ukuran perusahaan, serta mekanisme corporate governance yang diproksikan dengan dewan komisaris, dewan komisaris independen, dan komite audit. Pengujian dilakukan pada perusahaan indeks LQ45 selama periode 2018-2019. Sampel dipilih dengan teknik purposive sampling. Pengumpulan data menggunakan metode studi dokumen, serta dianalisis menggunakan analisis regresi linier berganda. Hasil analisis menunjukkan dewan komisaris berpengaruh negative serta komite audit memiliki pengaruh positif pada pengungkapan CSR. Sedangkan 4 (empat) penyebab lain yang diuji tidak berpengaruh.

Kata Kunci: Profitabilitas; Leverage; Ukuran Perusahaan; Pengungkapan Corporate Social Responsibility.
\end{abstract}

\section{Determinant Analysis of Corporate Social Responsibility Disclosures: A Study on LQ45 Index Companies}

\begin{abstract}
Companies should pay attention to Corporate Social Responsibility (CSR). Public companies are required to prepare a sustainability report, but the disclosure is voluntary, which causes the aspects that are reported by each company to be different. This difference is thought to be caused by several factors. The research objective is to examine the factors that are thought to affect CSR disclosure. The factors in question are profitability, leverage, company size, and corporate governance mechanisms proxied by board of commissioners, independent board of commissioners, and audit committee. Tests were carried out on the LQ45 index company during the 2018-2019 period. The sample was selected by purposive sampling technique. Data collection using document study method, and analyzed using multiple linear regression analysis. The results of the analysis show that board of commissioners has a negative effect and audit committee has a positive effect on CSR disclosure. Meanwhile, the other four causes tested had no effect.
\end{abstract}

Keywords: Profitability; Leverage; Company Size; Disclosure of Corporate Social Responsibility.

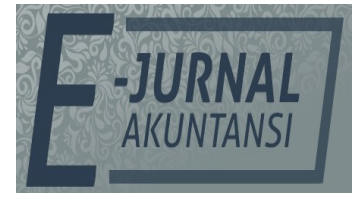

e-ISSN 2302-8556

Vol. 31 No. 7 Denpasar, Juli 2021 Hal. 1813-1827

10.24843/EJA.2021.v31.i07.p16

PENGUTIPAN:

Dwitarini, N.M., \& Sari,

M.M.R. (2021). Analisis

Determinan Pengungkapan

Corporate Social Responsibility:

Studi pada Perusahaan

Indeks LQ45. E-Jurnal

Akuntansi, 31(7), 1813-1827

RIWAYAT ARTIKEL: Artikel Masuk: 29 Januari 2021 Artikel Diterima: 1 April 2021

Artikel dapat diakses : https://ojs.unud.ac.id/index.php/Akuntansi/index 


\section{PENDAHULUAN}

Sektor bisnis dihadapkan dengan tantangan baru, dimana harus dapat menjembatani sistem sosial dan ekonomi. Perusahaan memiliki tanggung jawab lingkungan dan sosial, istilah Corporate Social Responsibility (CSR) muncul sebagai bentuk nyata dari pelaksanaan kewajiban perusahaan terhadap lingkungan sosial. Pemerintah Indonesia telah menerbitkan regulasi mengenai pelaksanaan dan pelaporan CSR bagi perusahaan. Perusahaan melaksanakan CSR untuk memenuhi tuntutan dari pemerintah dan masyarakat, selain itu perusahaan akan menerbitkan laporan tambahan mengenai pelaksanaan CSR perusahaan yang disebut Sustainability Report. Sustainability Report merupakan cara perusahaan mendapatkan legitimasi dari masyarakat. Bagi perusahaan Publik pengungkapan CSR penting untuk dilakukan karena berpengaruh positif terhadap harga saham (Anggraini, 2019), selain itu pengungkapan CSR juga berpengaruh positif terhadap aktivitas volume perdagangan saham (Vijaya, 2009) dengan begitu bagi perusahaan LQ45 yang diseleksi berdasarkan tingkat kapitalisasi dan liquiditas pengungkapan CSR sangat direkomendasikan.

Penyusunan laporan keberlanjutan diwajibkan bagi perusahaan publik yang diatur dalam Peraturan Otoritas Jasa Keuangan Nomor 51 / POJK.03/2017, namun untuk pengungkapannya masih bersifat sukarela. Hal inilah yang menyebabkan aspek-aspek yang dilaporkan pada setiap perusahaan berbeda. Perbedaan ini diduga disebabkan oleh beberapa faktor. Tujuan dari penelitian untuk melakukan pengujian atas faktor yang diduga mempunyai pengaruh pada pengungkapan CSR, factor-faktor yang dimaksud yakni profitabilitas, leverage, ukuran perusahaan, serta mekanisme corporate governance yang diproksikan dengan dewan komisaris, dewan komisaris independen, serta komite audit. Penelitian ini menggunakan teori stakeholders, teori agensi dan teori legitimasi.

Berdasarkan teori stakeholder, manajemen organisasi diharapkan untuk melakukan aktivitas yang dianggap penting oleh stakeholder mereka dan melaporkan kembali aktivitas tersebut kepada stakeholder. Berdasarkan teori stakeholder perusahaan dengan profitabilitas tinggi akan cenderung mengungkapkan CSR lebih luas untuk kebutuhan para stakeholdernya. Hal ini selaras dengan penelitian oleh (Utamie, Akram, \& Nugraha Ardana Putra, 2020) yang menunjukkan bahwa profitabilitas berpengaruh terhadap pengungkapan CSR. Berbeda halnya dengan temuan (Kristiana, Rispantyo, \& Kristianto, 2016) bahwa profitabilitas tidak mempengaruhi pengungkapan CSR.

Eisenhardt (1989) mengemukakan bahwa kontribusi utama teori agensi terletak pada fakta bahwa teori agensi mengidentifikasikan bagaimana memperlakukan informasi dan risiko dalam operasi suatu perusahaan. Teori keagenan memprediksi perusahaan dengan rasio leverage yang lebih tinggi akan mengungkapkan lebih banyak informasi. (Juhmani, 2014) menemukan Leverage berpengaruh terhadap pengungkapan CSR. Berbeda dengan temuan dari (Thuy Anh \& Tran, 2020) bahwa leverage tidak berpengaruh pada pengungkapan Corporate Social Responsibility. Jika dikaitkan dengan teori agensi, dewan komisaris digadang-gadang sebagai mekanisme pengendalian internal yang posisinya paling tinggi, dan mempunyai tanggung jawab melakukan monitoring atas tindakan manajemen tingkat puncak. Hasil penelitian oleh (Aminu Isa \& Muhammad, 2014) menyatakan, dewan komisaris mempunyai pengaruh pada 
pengungkapan Corporate Social Responsibility. Dewan komisaris independen digadang-gadang mampu memberi tekanan bagi suatu entitas untuk melakukan pengungkapan tanggung jawab sosialnya (Widyastari \& Ratna Sari, 2018). Hasil penelitian (Baba, 2017) menemukan bahwa dewan komisaris independen memengaruhi pengungkapan CSR, lain halnya dengan penelitian dari (Habbash, 2016) yang mendapatkan hasil bahwa dewan komisaris independen tidak mempunyai pengaruh terhadap pengungkapan Corporate Social Responsibility. Berdasarkan teori keagenan, disebutkan bahwa komite audit mampu meminimalisir konflik kepentingan yang terjadi antara manajemen dengan pemilik perusahaan. Hasil penelitian oleh (Sumilat \& Destriana, 2017) menyatakan bahwa komite audit tidak memengaruhi pengungkapan CSR, berbeda dengan penelitian dari (Utamie et al., 2020) yang mana penemuannya adalah komite audit mempunyai pengaruh dalam pengungkapan CSR.

Deegan, Robin dan Tobin (2000) menyatakan legitimasi dapat diperoleh ketika, antara keberadaan perusahaan tidak mengganggu eksistensi sistem nilai yang ada dalam masyarakat dan lingkungan. Menurut teori legitimasi, entitas besar melakukan kegiatan transaksi yang lebih banyak, hal ini tentunya membawa dampak lingkungan dan social yang lebih luas. Hasil penelitian yang dilakukan oleh (Tan, Benni, \& Liani, 2016), (Dias, Rodrigues, \& Craig, 2017), dan (Wang, Song, \& Yao, 2013) menyatakan bahwa ukuran perusahaan memengaruhi pengungkapan CSR. Di sisi lain penelitian dari (Dyduch \& Krasodomska, 2017) mendapatkan hasil, ukuran perusahaan tidak memengaruhi pengungkapan Corporate Social Responsibility.

Hasil penelitian-penelitian terdahulu yang bersifat inkonsisten satu dengan lainnya, menunjukkan bahwa isu mengenai pengungkapan Corporate Social Responsibility masih menjadi topik yang hangat dan berkemungkinan untuk berkembang kedepannya. Selain itu mengingat dikeluarkannya standar baru dalam pelaporan CSR yang dikeluarkan oleh GRI yang bernama GRI Standard memotivasi peneliti dalam meneliti isu mengenai pengungkapan CSR.

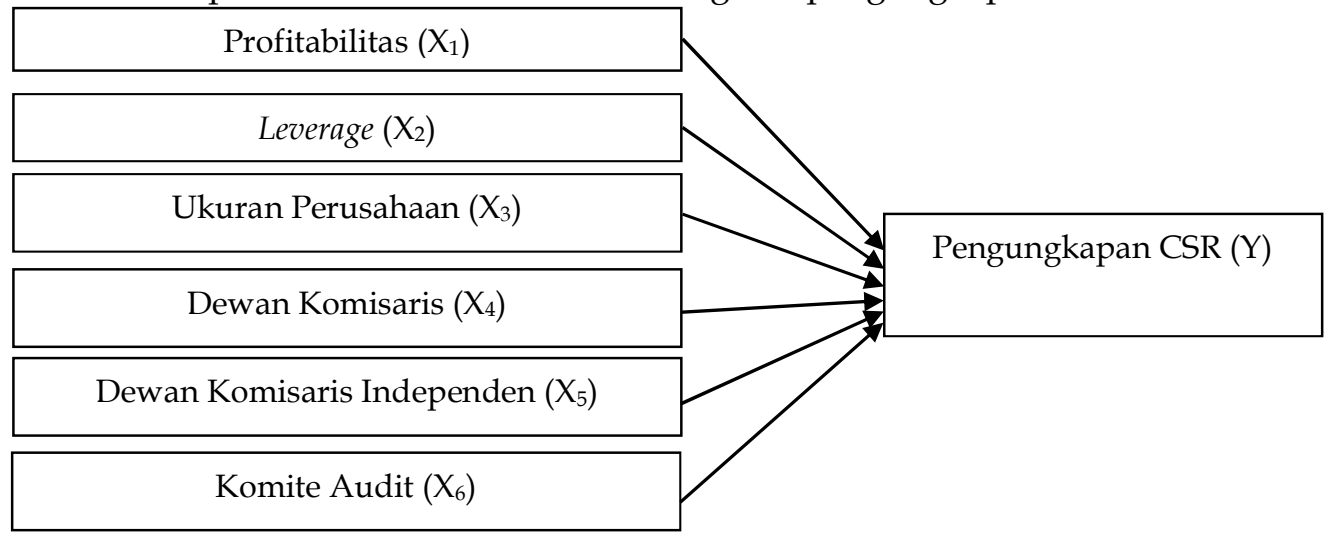

Gambar 1. Model Penelitian

Sumber: Data Penelitian, 2020

Profitabilitas merupakan kemampuan perusahaan dalam memanfaatkan asset yang dimiliki untuk menghasilkan laba atau profit selama satu periode. Berdasarkan stakeholders theory perusahaan dengan tingkat profitabilitas yang tinggi akan memenuhi kebutuhan para stakeholdersnya (Utamie et al., 2020). 
Temuan dari (Aini, 2015), (Istifaroh, 2017), (Mudjiyanti \& Maulani, 2017), (Wachira, 2017), dan (Utamie et al., 2020) menunjukkan bahwa profitabilitas berpengaruh terhadap pengungkapan CSR. Semakin tinggi tingkat profitabilitas mencerminkan semakin tinggi juga kemampuan perusahaan dalam menghasilkan laba, oleh karena itu perusahaan dapat meningkatkan tanggung jawab sosialnya, sehingga akan lebih luas pula pengungkapan pada laporan keberlanjutan perusahaan.

$\mathrm{H}_{1}$ : Profitabilitas berpengaruh Positif terhadap pengungkapan CSR.

Leverage dapat menggambarkan struktur modal perusahaan dan mengetahui risiko tak tertagihnya suatu utang oleh karena itu leverage dapat mencerminkan risiko keuangan perusahaan. Teori keagenan memprediksi perusahaan dengan struktur permodalan yang memiliki proporsi hutang yang lebih besar akan mempunyai biaya keagenan yang lebih tinggi (Jensen, M.C. \& Meckling, 1976) dalam Badjuri (2011). Temuan dari (Wahyuningsih \& Mahdar, 2019) dan (Akanfe, Michael, \& Bose, 2017) menyatakan bahwa leverage memiliki pengaruh pada pengungkapan CSR. Pengungkapan tanggung jawab sosial yang lebih luas dilakukan oleh entitas yang tingkat leverage-nya tinggi untuk mencegah sorotan dari kreditur.

$\mathrm{H}_{2}$ : leverage berpengaruh positif terhadap pengungkapan CSR.

Ukuran perusahaan adalah skala yang dipergunakan untuk menentukan besar/kecilnya perusahaan. Menurut teori agensi, entitas dengan skala yang besar mempunyai biaya keagenan yang besar pula jika dibandingkan dengan perusahaan kecil, sehingga perusahaan besar akan melakukan pengungkapan lebih luas dibandingkan perusahaan kecil (Utamie et al., 2020). Selain itu berdasarkan teori legitimasi, perusahaan besar melakukan aktivitas yang lebih banyak sehingga memiliki pengaruh lebih besar terhadap masyarakat, serta memiliki lebih banyak pemegang saham yang memiliki perhatian terhadap program sosial perusahaan (Sumilat \& Destriana, 2017). Temuan dari (Habbash, 2016), (Wuttichindanon, 2017), dan (Issa, 2017) menunjukkan bahwa ukuran perusahaan berpengaruh terhadap pengungkapan CSR. Semakin besar ukuran perusahaan maka akan membawa lebih banyak pengaruh terhadap sekitarnya, dan semakin besar pula tanggung jawab sosial dan lingkungan dari perusahaan tersebut. Dengan banyaknya tanggung jawab sosial yang wajib dilaksanakan maka akan memperluas pula pengungkapan CSR perusahaan.

$\mathrm{H}_{3}$ : Ukuran Perusahaan berpengaruh positif terhadap pengungkapan CSR.

Teori keagenan menyatakan, dewan komisaris merupakan mekanisme pengendalian internal yang posisinya paling tinggi, yang mempunyai tanggung jawab melakukan monitoring atas hal-hal yang dilakukan oleh manajemen tingkat puncak. Informasi CSR diharapkan dapat diungkapkan lebih luas dengan adanya monitoring yang lebih baik karena meminimalkan kemungkinan informasi yang ditutupi (Badjuri, 2011). Hasil penelitian yang dilakukan oleh (Rochayatun, 2016), (Susanto, 2019), dan (Aminu Isa \& Muhammad, 2014) menyatakan bahwa dewan komisaris berpengaruh terhadap pengungkapan CSR. Dengan adanya dewan komisaris pada suatu perusahaan diharapkan dapat terciptanya pengendalian yang baik pada perusahaan sehingga akan terciptanya pengungkapan informasi yang transparan.

$\mathrm{H}_{4}$ : Dewan komisaris berpengaruh positif terhadap pengungkapan CSR. 
Komisaris independen merupakan komisaris yang bukan pemegang saham mayoritas, anggota manajemen, pejabat atau dengan cara lain yang berhubungan tidak langsung atau langsung dengan pemegang saham mayoritas di suatu perusahaan yang melakukan pengawasan terhadap Tindakan pengelolaan perusahaan. Dalam suatu entitas, dewan komisaris independen digadang-gadang mampu memberi tekanan agar melakukan pengungkapan terhadap tanggung jawab sosial perusahaan (Widyastari \& Ratna Sari, 2018). Hasil penelitian (Baba, 2017) menemukan bahwa dewan komisaris independen berpengaruh terhadap pengungkapan CSR. Dengan adanya dewan komisaris independen diharapkan dapat melaksanakan pengawasan dengan baik terhadap keputusan dewan direksi, dimana dewan komisaris independen harus bersifat netral.

$\mathrm{H}_{5}$ : Dewan komisaris independen berpengaruh positif terhadap pengungkapan CSR.

Berdasarkan teori agensi, komite audit mampu meminimalisir adanya konflik kepentingan antara pemilik perusahaan dengan manajemen. Dalam hal pelaporan keuangan, peran dan tanggungjawab komite audit adalah memonitor dan mengawasi audit laporan keuangan dan memastikan agar standar dan kebijakan yang berlaku terpenuhi (Sumilat \& Destriana, 2017). Hasil penelitian dari (Utamie et al., 2020) menyatakan komite audit mempunyai pengaruh pada pengungkapan Corporate Social Responsibility. Berdasarkan tanggung jawabnya komite audit harusnya dapat mendorong manajemen untuk dapat melakukan pengungkapan mengenai pelaksanaan CSR secara transparan.

$\mathrm{H}_{6}$ : Komite Audit berpengaruh positif terhadap pengungkapan CSR.

\section{METODE PENELITIAN}

Penelitian ini termasuk penelitian kuantitatif dengan cara melakukan uji hipotesis, yang tujuannya adalah untuk menganalisis pengaruh variabel bebas $(X)$ terhadap variabel terikat $(Y)$. Variabel bebas yang dipergunakan di penelitian ini antara lain Profitabilitas $\left(X_{1}\right)$, Leverage $\left(X_{2}\right)$, Ukuran Perusahaan $\left(X_{3}\right)$, Dewan Komisaris $\left(X_{4}\right)$, Proporsi Dewan Komisaris Independen $\left(X_{5}\right)$, serta Komite Audit $\left(X_{6}\right)$ sedangkan variabel dependen adalah Pengungkapan CSR (Y). Lokasi penelitian ini dilakukan terhadap perusahaan yang masuk dalam golongan indeks LQ45 di Bursa Efek Indonesia (BEI).

Menurut The World Business Council for Sustainable Development dalam Rahman (2009:10) menjelaskan definisi CSR merupakan komitmen bisnis yang memberikan kontribusi pada pembangunan perekonomian berkelanjutan, bekerja dengan karyawan perusahaan, keluarga karyawan tersebut, berikut komunitas setempat (lokal) dan masyarakat secara keseluruhan dalam upaya memperbaiki kualitas hidup. Tingkat pengungkapan CSR dalam penelitian ini diukur dengan indicator berdasarkan GRI standard, dengan rumus Corporate Social Responsibility Disclosure Indeks (CSRDI).

Profitabilitas didefinisikan sebagai kemampuan suatu entitas dalam menghasilkan laba selama satu periode dengan memanfaatkan asset yang dimiliki perusahaan. Profitabilitas pada penelitian ini diukur dengan menggunakan Return On Asset (ROA). Leverage merupakan alat untuk mengukur besarnya tingkat ketergantungan perusahaan pada kreditur dalam hal pembiayaan aset perusahaan. Rasio leverage dapat diukur menggunakan DER (Debt to Equity Ratio) 
yaitu rasio jumlah hutang terhadap jumlah modal sendiri. Ukuran perusahaan pada penelitian ini diukur dengan mentransformasikan total aset ke dalam bentuk logaritma natural, tujuannya untuk menyamakan dengan variabel lain karena total aset perusahaan memiliki nilai yang relatif lebih besar dari variabel lain dalam penelitian.

Ukuran Dewan Komisaris merupakan banyaknya dewan yang bertugas melakukan pengawasan dan memberi nasihat kepada direktur atau direksi. Adapun pengukurannya dengan menjumlahkan total dewan komisaris pada suatu perusahaan. Komisaris independen adalah seseorang yang tidak mempunyai afiliasi dengan pemegang saham pengendali, dengan dewan direksi atau dewan komisaris serta tidak sedang menjabat sebagai direktur pada perusahaan yang memiliki kaitan dengan perusahaan pemilik menurut peraturan yang dikeluarkan oleh BEI. Komisaris independen diukur dengan proporsi dewan komisaris Independen diukur dengan rasio perbandingan jumlah komisaris independen dengan total dewan komisaris. Komite audit adalah komite yang bekerja sama dalam melaksanakan tugas dan fungsi Dewan Komisaris yang dibentuk oleh Dewan Komisaris. Komite audit diukur dengan cara menjumlahkan anggota komite audit yang ada di perusahaan dan tercantum pada laporan tahunan.

Penelitian ini menggunakan data kuantitatif dan kualitatif. Sumber data yang dipakai pada penelitian ini ialah sumber data sekunder. Populasi di penelitian ini ialah perusahaan yang telah listing di BEI yang termasuk bagian dari perusahaan indeks LQ45. Sampel penelitian ini berjumlah 21 perusahaan yang dipilih dengan metode non probability sampling, teknik purposive sampling. Dalam penelitian ini, teknik pengumpulan data yang digunakan adalah metode studi dokumen, yakni jenis pengumpulan data yang meneliti berbagai macam dokumen yang berguna untuk bahan analisis.

\section{Tabel 1. Seleksi Sampel berdasarkan Kriteria}

\begin{tabular}{|c|c|c|}
\hline & Kriteria & Sampel \\
\hline 1) & Perusahaan yang terdaftar sebagai indeks LQ45 tahun 2018 dan 2019 & 50 \\
\hline 2) & $\begin{array}{l}\text { Perusahaan yang terdaftar sebagai indeks LQ45 berturut-turut tahun } \\
\text { 2018-2019 }\end{array}$ & $(15)$ \\
\hline 3) & $\begin{array}{l}\text { Perusahaan yang melakukan pengungkapan CSR pada laporan } \\
\text { keberlanjutannya tahun } 2018-2019\end{array}$ & $(13)$ \\
\hline 4) & $\begin{array}{l}\text { Perusahaan yang melakukan pengungkapan CSR pada laporan } \\
\text { keberlanjutannya tahun 2018-2019 berdasarkan GRI Standard }\end{array}$ & $(1)$ \\
\hline & Total Sampel & 21 \\
\hline
\end{tabular}

Sumber: Data Penelitian, 2020

Pengujian hipotesis penelitian menggunakan analisis regresi linear berganda. Analisis regresi linier berganda bisa diukur dengan koefisien determinasi, nilai statistik $\mathrm{F}$, serta nilai statistik t. Analisis regresi menggunakan aplikasi Eviews 10 Sebelum melakukan analisis regresi berganda untuk menguji hipotesis, diperlukan adanya pengujian asumsi klasik. Analisis regresi linier berganda akan dilakukan jika jumlah dari variabel independennya minimal 2 (Sugiyono, 2017:275). Persamaan regresi linier berganda penelitian ini dapat dirumuskan sebagai berikut.

$$
Y=\alpha+\beta_{1} X_{1}+\beta_{2} X_{2}+\beta_{3} X_{3}+\beta_{4} X_{4}+\beta_{5} X_{5}+\beta_{6} X_{6}+\varepsilon
$$




\section{HASIL DAN PEMBAHASAN}

Analisis statistik deskriptif digunakan untuk memberikan gambaran umum dari data yang digunakan.

Tabel 2. Statistik Deskriptif

\begin{tabular}{lrrrrrrr}
\hline & $\mathrm{Y}$ & \multicolumn{1}{c}{$\mathrm{X}_{1}$} & \multicolumn{1}{c}{$\mathrm{X}_{2}$} & \multicolumn{1}{c}{$\mathrm{X}_{3}$} & \multicolumn{1}{c}{$\mathrm{X}_{4}$} & \multicolumn{1}{c}{$\mathrm{X}_{5}$} & \multicolumn{1}{c}{$\mathrm{X}_{6}$} \\
\hline Mean & 0,339 & 6,325 & 2,740 & 11,377 & 6,667 & 0,415 & 4,023 \\
Median & 0,286 & 3,450 & 2,060 & 11,139 & 6,000 & 0,333 & 4,000 \\
Maximum & 0,948 & 46,000 & 11,300 & 14,164 & 10,000 & 0,833 & 6,000 \\
Minimum & 0,091 & $-6,000$ & 0,140 & 8,517 & 3,000 & 0,200 & 3,000 \\
Std. Dev. & 0,196 & 9,230 & 2,687 & 1,487 & 1,691 & 0,135 & 1,024 \\
Observations & 42 & 42 & 42 & 42 & 42 & 42 & 42 \\
\hline
\end{tabular}

Sumber: Data Penelitian, 2020

Berdasarkan Table 2, variabel Pengungkapan CSR (Y) tertinggi pada perusahaan yang tergolong indeks LQ45 sebesar 0,948 yang terjadi pada PT WSKT Tbk tahun 2018-2019 dan pengungkapan CSR terendah sebesar 0,091 terjadi pada PT BBNI tahun 2019. Variabel profitabilitas $\left(X_{1}\right)$ tertinggi pada perusahaan yang tergolong indeks LQ45 sebesar 46 yang terjadi pada PT UNVR Tbk tahun 2018 dan profitabilitas terendah sebesar -6 terjadi pada PT EXCL Tbk tahun 2018. Variabel leverage $\left(\mathrm{X}_{2}\right)$ tertinggi pada perusahaan yang tergolong indeks LQ45 sebesar 11,300 yang terjadi pada PT BBTN tahun 2019 dan leverage terendah sebesar 0,140 terjadi pada PT INCO Tbk tahun 2019. Variabel ukuran perusahaan $\left(X_{3}\right)$ tertinggi pada perusahaan yang tergolong indeks LQ45 sebesar 14,164 yang terjadi pada PT BBRI Tbk tahun 2019 dan ukuran perusahaan terendah sebesar 8,517 terjadi pada PT ASII Tbk tahun 2018.

Variabel dewan komisaris $\left(\mathrm{X}_{4}\right)$ tertinggi pada perusahaan yang tergolong indeks LQ45 sebesar 10 yang terjadi pada PT ASII Tbk tahun 2018-2019 dan PT BBRI tahun 2018 dan dewan komisaris terendah sebesar 3 terjadi pada PT AKRA Tbk tahun 2018-2019. Variabel dewan komisaris independen $\left(X_{5}\right)$ tertinggi pada perusahaan yang tergolong indeks LQ45 sebesar 0,833 yang terjadi pada PT UNVR Tbk tahun 2018 dan dewan komisaris terendah sebesar 0,2 terjadi pada PT INCO Tbk tahun 2019. Variabel Komite audit $\left(\mathrm{X}_{6}\right)$ tertinggi pada perusahaan yang tergolong indeks LQ45 sebesar 6 terjadi pada PT BMRI tahun 2018-2019, PT BBRI dan BBTN tahun 2018, PT PGAS dan PT WIKA tahun 2019 dan dewan komisaris terendah sebesar 3 terjadi pada PT AKRA, PT BBCA, PT KLBF, PT MEDC, PT PTPP, PT UNVR dan UNTR tahun 2018-2019. Data yang terkumpul sebelumnya dilakukan uji asumsi klasik untuk mendapatkan kelayakan. Tujuan dari uji asumsi klasik adalah untuk mengetahui hubungan yang berarti antara variabel independen dengan variabel dependen sehingga hasil yang diperoleh lebih akurat, efisien, dan terbatas dari kelemahan-kelemahan yang disebabkan oleh gejala asumsi klasik normalitas, multikolinearitas, dan heteroskedastisitas. 


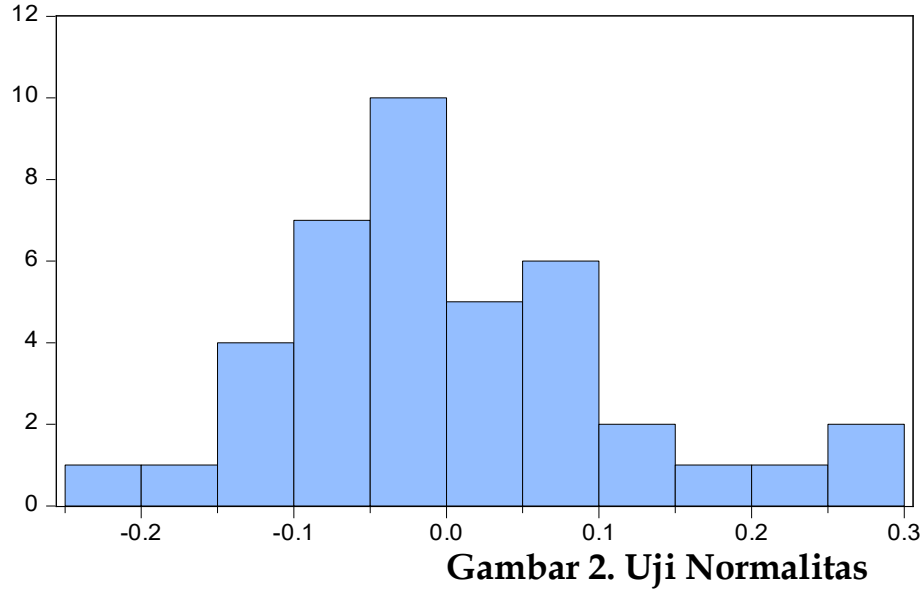

\begin{tabular}{|lr|}
\hline \multicolumn{2}{|l|}{ Series: Residuals } \\
Sample 1 40 \\
Observations & 40 \\
& \\
Mean & $1.77 \mathrm{e}-17$ \\
Median & -0.007279 \\
Maximum & 0.274050 \\
Minimum & -0.212065 \\
Std. Dev. & 0.108945 \\
Skewness & 0.629791 \\
Kurtosis & 3.323937 \\
& \\
Jarque-Bera & 2.819136 \\
Probability & 0.244249 \\
\hline
\end{tabular}

Sumber: Data Penelitian, 2020

Berdasarkan hasil uji normalitas dengan menggunakan uji Jarque-Bera diketahui bahwa nilai Prob. JB hitung sebesar 0,000 $<0,05$ sehingga diperoleh kesimpulan residual tidak terdistribusi normal yang berarti tidak terpenuhinya asumsi klasik tentang kenormalan. Dalam memenuhi asumsi normalitas dilakukan penyembuhan data dengan menggunakan uji outlier atau melakukan transformasi data. Penelitian ini melakukan uji outlier dengan membuang 2 data perusahaan yaitu PT WSKT pada tahun 2018-2019, sehingga data yang semula berjumlah 42 menjadi 40 data. Setelah itu dilakukan kembali uji normalitas dan menghasilkan nilai Prob. JB hitung sebesar 0,244 > 0,05 maka diperoleh kesimpulan bahwa residual memiliki distribusi normal, artinya asumsi klasik tentang kenormalan telah dipenuhi.

Tabel 3. Hasil Uji Multikolinieritas

\begin{tabular}{cccr}
\hline Variable & Coefficient Variance & Uncentered VIF & Centered VIF \\
\hline $\mathrm{C}$ & 0,044 & 125,586 & $\mathrm{NA}$ \\
$\mathrm{X}_{1}$ & 1,590 & 5,841 & 3,943 \\
$\mathrm{X}_{2}$ & 0,000 & 5,429 & 2,719 \\
$\mathrm{X}_{3}$ & 0,001 & 187,933 & 3,236 \\
$\mathrm{X}_{4}$ & 0,000 & 20,644 & 1,282 \\
$\mathrm{X}_{5}$ & 0,100 & 54,473 & 5,374 \\
$\mathrm{X}_{6}$ & 0,000 & 26,700 & 1,544 \\
\hline
\end{tabular}

Sumber: Data Penelitian, 2020

Jika dilihat dari hasil uji nilai VIF untuk variabel independen profitabilitas $\left(X_{1}\right)$, leverage $\left(X_{2}\right)$, ukuran perusahaan $\left(X_{3}\right)$, dewan komisaris $\left(X_{4}\right)$, proporsi dewan komisaris independen $\left(X_{5}\right)$ dan komite audit $\left(X_{6}\right)<10$, sehingga diperoleh kesimpulan bahwa keenam variabel independen yang digunakan tidak mengalami masalah multikolinieritas.

Tabel 4. Hasil Uji Heteroskedastisitas

\begin{tabular}{|c|c|c|}
\hline \multicolumn{3}{|c|}{ Heteroskedasticity Test: Breusch-Pagan-Godfrey } \\
\hline F-statistic & $1,521 \quad$ Prob. $F(6,33)$ & 0,202 \\
\hline Obs*R-squared & Prob. Chi-Square(6) & 0,193 \\
\hline Scaled explained SS & 6,852 Prob. Chi-Square(6) & 0,335 \\
\hline
\end{tabular}

Sumber: Data Penelitian, 2020 
Berdasarkan hasil uji Breusch Pagan Godfrey diketahui bahwa nilai prob.obs ${ }^{*} r$ squared memiliki nilai > alpha 0,05 yaitu sebesar 0,193, jadi diperoleh kesimpulan bahwa tidak ada masalah heteroskedastisitas pada model regresi.

Tabel 5. Hasil Uji Autokorelasi

\begin{tabular}{lrlr}
\hline \multicolumn{4}{c}{ Breusch-Godfrey Serial Correlation LM Test } \\
\hline F-statistic & 1,171 & Prob. F(2,31) & 0,323 \\
Obs ${ }^{*}$-squared & 2,810 & Prob. Chi-Square(2) & 0,245 \\
\hline
\end{tabular}

Sumber: Data Penelitian, 2020

Berdasarkan hasil uji Langrange Multiplier diketahui bahwa nilai prob.obs ${ }^{*} r$ squared sebesar 0,245>0,05, sehingga diperoleh kesimpulan bahwa tidak terjadi masalah autokorelasipada data yang digunakan dalam penelitian.

Analisis regresi linier berganda, bertujuan untuk mengetahui hubungan antara lebih dari dua variabel, yaitu variabel dependen dan variabel independen. Analisis regresi linier berganda akan dilakukan apabila jumlah dari variabel independennya minimal 2 (Sugiyono, 2017:275).

Tabel 6. Koefisien Determinasi $\left(\mathbf{R}^{2}\right)$

\begin{tabular}{lr}
\hline$R$-Square & Adjusted-R Square \\
\hline 0,413 & 0,307
\end{tabular}

Sumber: Data Penelitian, 2020

Berdasarkan hasil pengujian pada Tabel 6, nilai yang didapatkan dari koefisien determinasi $R$-Square sebesar 0,413. Penelitian ini memakai (6) enam variabel bebas, maka nilai adjusted $R$-Square dipergunakan untuk mengukur proporsi pengaruh variabel bebas terhadap variabel terikat. Nilai adjusted $r$ square sebesar 0,307, memperlihatkan proporsi pengaruh profitabilitas, leverage, ukuran perusahaan, dewan komisaris, proporsi dewan komisaris independen serta komite audit pada pengungkapan CSR pada perusahan yang tergolong indeks LQ45 sebesar 30,72 persen sedangkan sisanya 69,28 persen (100 - 30,72 persen) dipengaruhi oleh variabel lain yang tidak diteliti pada penelitian.

Tabel 7. Hasil Uji Statistik F

\begin{tabular}{lrlr}
\hline$R$-squared & 0,414 & Mean dependent var & 0,309 \\
Adjusted R-squared & 0,307 & S.D. dependent var & 0,142 \\
S.E. of regression & 0,118 & Akaike info criterion & $-1,271$ \\
Sum squared resid & 0,465 & Schwarz criterion & $-0,976$ \\
Log likelihood & 32,425 & Hannan-Quinn criter. & $-1,164$ \\
F-statistic & 3,882 & Durbin-Watson stat & 1,612 \\
Prob(F-statistic) & 0,005 & & \\
\hline
\end{tabular}

Sumber: Data Penelitian, 2020

Berdasarkan Tabel 7, diketahui bahwa nilai prob. F (Statistic) sebesar 0,005 lebih kecil dari tingkat signifikansi 0,05, sehingga diperoleh kesimpulan bahwa model penelitian sudah layak atau cocok untuk memprediksi dan menjelaskan pengaruh profitabilitas, leverage, ukuran perusahaan, dewan komisaris, proporsi dewan komisaris independen dan komite audit terhadap pengungkapan CSR dengan kata lain profitabilitas, leverage, ukuran perusahaan, dewan komisaris, 
DWITARINI, N.M., \& SARI, M.M.R. ANALISIS DETERMINAN PENGUNGKAPAN...

proporsi dewan komisaris independen dan komite audit secara bersamaan memengaruhi pengungkapan CSR pada perusahaan yang tergolong indeks LQ45. Tabel 8. Hasil Uji t

\begin{tabular}{ccccc}
\hline Variable & Coefficient & Std. Error & t-Statistic & Prob. \\
\hline C & 0,508 & 0,210 & 2,422 & 0,021 \\
$X_{1}$ & 0,005 & 0,004 & 1,219 & 0,232 \\
$X_{2}$ & 0,002 & 0,011 & 0,138 & 0,891 \\
$X_{3}$ & $-0,007$ & 0,022 & $-0,318$ & 0,752 \\
$X_{4}$ & $-0,031$ & 0,012 & $-2,529$ & 0,016 \\
$X_{5}$ & $-0,498$ & 0,317 & $-1,573$ & 0,125 \\
$X_{6}$ & 0,064 & 0,023 & 2,773 & 0,009 \\
\hline
\end{tabular}

Sumber: Data Penelitian, 2020

Hipotesis pertama $\left(\mathrm{H}_{1}\right)$ menyebutkan bahwa profitabilitas berpengaruh positif terhadap pengungkapan CSR. Hasil analisis regresi linier berganda menggunakan uji t pada Tabel 8, variabel profitabilitas yang diukur dengan return on assets memiliki nilai probabilitas sebesar 0,232 , jadi nilai probabilitas variabel profitabilitas $\left(X_{1}\right)>$ nilai probabilitas kritis $(\alpha=5 \%)$, hal ini menunjukan bahwa profitabilitas tidak berpengaruh terhadap variabel pengungkapan CSR. Hal tersebut berarti pengungkapan tanggung jawab sosial perusahaan tidak dipengaruhi oleh besar kecilnya profitabilitas perusahaan, dikarenakan laba perusahaan diprioritaskan untuk kegiatan operasional, yang menyebabkan pemanfaatan untuk aktivitas sosial lebih kecil. Perusahaan dengan profitabilitas tinggi lebih berorientasi pada laba semata, sehingga belum tentu lebih banyak melakukan aktivitas sosial (Rofiqkoh \& Priyadi, 2016). Hasil penelitian ini sejalan dengan penelitian yang dilakukan oleh (Sumilat \& Destriana, 2017), (Kristiana et al., 2016), dan (Rofiqkoh \& Priyadi, 2016) yang menunjukkan bahwa profitabilitas tidak berpengaruh pada pengungkapan CSR.

Hipotesis kedua $\left(\mathrm{H}_{2}\right)$ menyebutkan bahwa leverage mempunyai pengaruh positif pada pengungkapan CSR. Jika dilihat pada hasil uji t pada Tabel 8, nilai probabilitas variabel leverage $\left(X_{2}\right)>$ nilai probabilitas kritis $(\alpha=5 \%)$ sebesar 0,891 $>0,05$, hal ini menunjukan bahwa leverage tidak berpengaruh terhadap variabel pengungkapan CSR. Stakeholders theory menyatakan bahwa perusaahan akan cenderung mengurangi kinerja sosial dan lingkungannya apabila memiliki tingkat leverage lebih tinggi. Ini dilakukan untuk tetap melindungi kepercayaan dari pihak stakeholders terutama kreditur, karena dalam menjalankan operasinya suatu perusahaan memperoleh pinjaman dana dari pihak eksternal. Oleh karena itu agar tidak menjadi perhatian dari pihak kreditur perusahaan akan mengurangi pengeluaran terkait dengan informasi yang mampu mereduksi laba perusahaan (Utamie et al., 2020). Hasil penelitian ini sejalan dengan penelitian yang dilakukan oleh (Sumilat \& Destriana, 2017), (Kristiana et al., 2016), (Thuy Anh \& Tran, 2020), dan (Utamie et al., 2020) yang menyatakan leverage tidak berpengaruh terhadap pengungkapan CSR.

Hipotesis ketiga $\left(\mathrm{H}_{3}\right)$ menyebutkan bahwa ukuran perusahaan memiliki pengaruh positif pada pengungkapan Corporate Social Responsibility. Berdasarkan hasil uji t pada Tabel 8, nilai probabilitas variabel ukuran perusahaan $\left(X_{3}\right)>$ nilai probabilitas kritis $(\alpha=5 \%)$ sebesar $0,752>0,05$, hal ini menunjukan bahwa ukuran perusahaan tidak berpengaruh terhadap variabel pengungkapan CSR. Hal ini 
dapat terjadi karena penelitian ini dilakukan pada perusahaan Indeks LQ45 yang dimana notabene merupakan perusahaan besar yang rata rata perusahaannya memiliki nilai total asset yang tinggi sehingga pada penelitian ini ukuran perusahaan tidak berpengaruh terhadap pengungkapan CSR. Selain itu dilihat dari penelitian sebelumnya yang menggunakan variabel yang sama dengan sampel yang berbeda, beberapa penelitian memperoleh hasil serupa, keadaan ini memperlihatkan bahwa perusahaan besar tidak akan seterusnya melakukan pengungkapan tanggung jawab sosial yang lebih luas agar mempunyai pengaruh pada pihak-pihak internal maupun eksternal yang mempunyai kepentingan terhadap perusahaan untuk mendapatkan legitimasi dari para stakeholders. Hal ini disebabkan karena tanggung jawab sosial perusahaan sudah menjadi sebuah keharusan bagi perusahaan guna menjaga keberlangsungan hidup perusahaan, dilihat dari POJK Nomor 51/POJK.03//2017 tentang Penerapan Keuangan Keberlanjutan Kepada Lembaga Lasa Keuangan, Emiten dan Perusahaan Publik, emiten dan perusahaan publik wajib melaporkan sustainability report. Hal ini menyebabkan besar-kecilnya ukuran perusahaan tidak berpengaruh pada besarnya tingkat tanggung jawab sosial suatu entitas (Marfu'ah \& Cahyo, 2011) dalam Putri, 2013). Hasil penelitian ini sejalan dengan hasil penelitian dari (Putri, 2013) yang menyatakan ukuran perusahaan tidak mempunyai pengaruh pada pengungkapan CSR. Hasil penelitian ini tidak selaras dengan hasil dari penelitian dari (Tan et al., 2016) dan (Wang et al., 2013) yang menyatakan bahwa ukuran perusahaan berpengaruh terhadap pengungkapan CSR.

Hipotesis keempat $\left(\mathrm{H}_{4}\right)$ menyebutkan bahwa dewan komisaris memiliki pengaruh positif pada pengungkapan CSR. Jika dilihat dari hasil uji t pada Tabel 8 , nilai probabilitas variabel dewan komisaris $\left(\mathrm{X}_{4}\right)<$ nilai probabilitas kritis $(\alpha=$ $5 \%$ ) sebesar $0,016<0,05$, hal ini menunjukan bahwa dewan komisaris mempunyai pengaruh pada variabel pengungkapan CSR. Koefisien regresi sebesar -0.031 menunjukkan arah negatif, artinya dewan komisaris berpengaruh negatif terhadap pengungkapan CSR pada perusahaan yang tergolong indeks LQ45. Hal ini disebabkan oleh dewan komisaris yang jumlahnya sedikit dapat menunjukkan efektivitas yang baik pada pengawasan manajemen suatu entitas. Tidak hanya itu, dewan komisaris dengan jumlah yang besar dapat menjadi kurang efektif dikarenakan adanya anggota dewan komisaris yang mementingkan kepentingan pribadi ataupun kepentingan kelompoknya. Oleh karena itu, sebaiknya memperhatikan komposisi, kemampuan, dan integritas anggota dalam pembentukan dewan komisaris sehingga dewan komisaris dapat melakukan fungsi pengawasan, pengendalian dan memberikan arahan yang baik demi kepentingan perusahaan (Waryanto, 2010) dalam (Nur \& Priantinah, 2012). Hasil penelitian ini selaras dengan hasil penelitian (Nur \& Priantinah, 2012) yang menyatakan dewan komisaris berpengaruh negatif terhadap pengungkapan CSR.

Hipotesis kelima $\left(\mathrm{H}_{5}\right)$ menyebutkan bahwa dewan komisaris independen mempunyai pengaruh pada pengungkapan CSR. Jika dilihat dari hasil uji t pada Tabel 8, nilai probabilitas variabel proporsi dewan komisaris independen $\left(\mathrm{X}_{5}\right)>$ nilai probabilitas kritis $(\alpha=5 \%)$ sebesar $0,125>0,05$, hal ini menunjukan bahwa proporsi dewan komisaris independen tidak memiliki pengaruh pada variabel pengungkapan CSR. Hal ini kemungkinan terjadi karena penunjukan serta pengangkatan dewan komisaris independen yang sifatnya kurang efektif, selain 
itu terdapat isu yang menyatakan bahwa dewan komisaris independen hanya berupa atas nama saja, yang mana dewan komisaris independen tidak ditunjuk secara nyata (Rochayatun, 2016). Menurut Restuningdiah (2010) dalam (Putri, 2013), dalam pengambilan keputusan kompetensi Dewan Komisaris memegang peranan penting, sehingga untuk dapat meningkatkan kualitas pengambilan keputusan pada tingkat komisaris terkait dengan CSR tidak hanya komposisi Dewan Komisaris Independen yang menjadi pertimbangan, melainkan juga kompetensi dan latar belakang pendidikan. Hasil penelitian ini selaras dengan hasil penelitian yang dilakukan oleh (Putri, 2013) dan (Rochayatun, 2016) yang menyatakan dewan komisaris independen tidak berpengaruh terhadap pengungkapan CSR.

Hipotesis keenam $\left(\mathrm{H}_{6}\right)$ menyebutkan bahwa komite audit memiliki pengaruh positif pada pengungkapan CSR. Berdasarkan hasil uji t pada Tabel 8, nilai probabilitas variabel komite audit $\left(X_{6}\right)<$ nilai probabilitas kritis $(\alpha=5 \%)$ sebesar 0,009 < 0,05, hal ini menunjukan bahwa komite audit berpengaruh terhadap variabel pengungkapan CSR. Hal ini mendukung agency theory yang menyatakan bahwa dengan adaya komite audit dalam suatu perusahaan dapat meminimalisir konflik kepentingan antara manajemen dan pemilik perusahaan. Jumlah komite audit sangat penting bagi pengawasan dan pengendalian perusahaan sehingga dengan adanya komite audit pada suatu perusahaan maka akan menambah efektifitas pengawasan termasuk praktik dan pengungkapan CSR. Hal ini dikarenakan tugas pengawasan terhadap laporan keuangan dilaksanakan secara baik, dan telah disesuaikan dengan peraturan oleh komite audit dan komite audit bersikap jujur (Rochayatun, 2016). Hasil penelitian ini selaras dengan penelitian (Utamie et al., 2020) dan (Rochayatun, 2016) yang menyebutkan bahwa komite audit mempunyai pengaruh positif pada pengungkapan CSR.

\section{SIMPULAN}

Jika dilihat dari hasil analisis yang dilakukan sebelumnya, dapat disimpulkan bahwa Profitabilitas tidak berpengaruh terhadap pengungkapan CSR pada perusahaan indeks LQ45 yang terdaftar di Bursa Efek Indonesia tahun 2018-2019. Perusahaan dengan profitabilitas tinggi lebih terorientasi pada laba semata jadi belum tentu lebih banyak melakukan kegiatan sosial.

Leverage tidak memiliki pengaruh pada pengungkapan CSR di perusahaan indeks LQ45 yang listing di Bursa Efek Indonesia (BEI) tahun 2018-2019. Menurut stakeholders theory bahwa untuk tetap menjaga kepercayaan dari pihak stakeholders terutama kreditur, perusaahan dengan tingkat leverage lebih tinggi akan cenderung mengurangi kinerja sosial dan lingkungannya.

Ukuran Perusahaan tidak berpengaruh terhadap pengungkapan CSR pada perusahaan indeks LQ45 yang terdaftar di Bursa Efek Indonesia tahun 2018-2019. Hal ini dikarenakan tanggung jawab sosial perusahaan merupakan sebuah kewajiban bagi perusahaan yang berguna untuk menjaga kelangsungan hidup perusahaan, dan bukan lagi menjadi sekedar kegiatan.

Dewan Komisaris berpengaruh negatif terhadap pengungkapan CSR pada perusahaan indeks LQ45 yang listing di Bursa Efek Indonesia tahun 2018-2019. Hal 
ini dikarenakan dewan komisaris yang berjumlah kecil cenderung memiliki efektivitas yang baik terhadap pengawasan manajemen perusahaan.

Dewan Komisaris Independen tidak mempunyai pengaruh pada pengungkapan CSR pada perusahaan indeks LQ45 yang terdaftar di Bursa Efek Indonesia tahun 2018-2019. Hal ini terjadi dimungkinkan karena pengangkatan dan pemilihan dewan komisaris independen yang kurang efektif.

Komite Audit berpengaruh positif terhadap pengungkapan CSR pada perusahaan indeks LQ45 yang terdaftar di Bursa Efek Indonesia tahun 2018-2019. Konflik kepentingan antara manajemen dan pemilik perusahaan dapat diminimalisir dengan adanya komite audit.

Berdasarkan hasil penelitian yang telah dilakukan, terdapat beberapa kekurangan dalam penelitian ini yakni hanya menggunakan jangka waktu dua tahun serta sampel yang terbatas. Guna memperoleh hasil yang lebih baik serta mengetahui konsistensi pengaruh variabel bebas pada variabel terikat, peneliti selanjutnya diharapkan dapat menggunakan jangka waktu yang lebih panjang. Serta peneliti selanjutnya dapat menggunakan alat ukur yang berbeda dan sampel yang berbeda pula dalam menguji variabel.

\section{REFERENSI}

Aini, A. K. (2015). Pengaruh Karakteristik Perusahaan Terhadap Pengungkapan Tanggung Jawab Sosial Perusahaan (CSR) Pada Perusahaan Yang Terdaftar Di Indeks LQ45 Bursa Saham Indonesia (BEI). Jurnal Ilmiah Mahasiswa FEB $U B, 1(2), 1-14$.

Akanfe, S. K., Michael, S. O., \& Bose, A. D. (2017). Determinant of Corporate Social Responsibility Disclosure in Nigeria. International Journal of Academic Research in Business and Social Sciences, 7(7), 565-580. https://doi.org/10.6007/ijarbss/v7-i7/3122

Aminu Isa, M., \& Muhammad, S. (2014). The Impact of Board Characteristics on Corporate Social Responsibility Disclosure: Evidence from Nigerian Food Product Firms. International Journal of Management Science and Business Administration, 1(12), 34-45. https://doi.org/10.18775/ijmsba.1849-56645419.2014.112.1004

Anggraini, L. F. (2019). Pengaruh Kinerja Keuangan, Ukuran Perusahaan, Pengungkapan Corporate Social Responsibility (CSR) Terhadap Harga Saham. Global Journal of Management And Business ..., 19(8). Retrieved from https://journalofbusiness.org/index.php/GJMBR/article/view/2805

Baba, H. N. (2017). The Determinants of Corporate Social Responsibility Disclosure: The Case of Malaysian Government-Linked Companies in $\begin{array}{lllll}\text { Malaysia. SHS Web of Conferences, 36, } 00029 . & .\end{array}$ https://doi.org/10.1051/shsconf/20173600029

Badjuri, A. (2011). Corporate Governance Mechanism , Fundamental Factors, Corporate Social Responsibility ( Csr ) Disclosure Of A Natural Resource And Manufactur Company In Indonesian. Dinamika Keuangan Dan Perbankan.

Dias, A., Rodrigues, L. L., \& Craig, R. (2017). Corporate governance effects on social responsibility disclosures. Australasian Accounting, Business and Finance Journal, 11(2), 3-22. https://doi.org/10.14453/aabfj.v11i2.2

Dyduch, J., \& Krasodomska, J. (2017). Determinants of corporate social 
responsibility disclosure: An empirical study of Polish listed companies. Sustainability (Switzerland), 9(11). https://doi.org/10.3390/su9111934

Habbash, M. (2016). Corporate governance and corporate social responsibility disclosure: evidence from Pakistan. Corporate Governance (Bingley), 16(5), 785797. https:// doi.org/10.1108/CG-05-2016-0100

Issa, A. I. F. (2017). The Factors Influencing Corporate Social Responsibility Disclosure in the Kingdom of Saudi Arabia. Australian Journal of Basic and Applied Sciences, 11(July), 1-19.

Istifaroh, A. (2017). Faktor-Faktor Yang Mempengaruhi Pengungkapan Corporate Social Responsibility. 6.

Jensen, M.C.; Meckling, W. H. (1976). Theory of the firm: Managerial behavior, agency cost, and capital structure. Journal of Financial Economics, 3(4), 305-360.

Juhmani, O. (2014). Determinants of corporate social and environmental disclosure on websites: the case of Bahrain. Universal Journal of Accounting and Finance, 2(4), 77-87. https://doi.org/10.13189/ujaf.2014.020402

Kristiana, C., Rispantyo, \& Kristianto, D. (2016). Analisis Faktor-Faktor yang Mempengaruhi Pengungkapan CSR pada Perusahaan Manufaktur Sektor Industri Barang Konsumsi. Jurnal Akuntansi Dan Sistem Teknologi Informasi, 12(April), 150-158.

Mudjiyanti, R., \& Maulani, S. S. (2017). Pengaruh Likuiditas Dan Profitabilitas Terhadap Pengungkapan Corporate Social Responsibilitypada Perusahaan Terdaftar Di Bursa Efek Indonesia. 11(Zr2011dl0 2), 57-64. https://doi.org/10.13937/j.cnki

Nur, M., \& Priantinah, D. (2012). Analisis Faktor-Faktor Yang Mempengaruhi Pengungkapancorporate Social Responsibility Di Indonesia (Studi Empiris Pada Perusahaan Berkategori High Profile Yang Listing Di Bursa Efek Indonesia). Nominal, Barometer Riset Akuntansi Dan Manajemen, 1(2). https://doi.org/10.21831/nominal.v1i2.996

Putri, C. D. (2013). Pengaruh Corporate Governance Dan Karakteristik Perusahaan Terhadap Pengungkapan Tanggung Jawab Sosial Perusahaan Di Dalam Sustainability Report (Studi Empiris Perusahaan yang Terdaftar di BEI). (September).

Rochayatun, S. (2016). Faktor-faktor Yang Mempengaruhi Corporate Social Responsibility (CSRD). Jurnal Penelitian Ilmu Ekonomi WIGA, 6(1), 63-79.

Rofiqkoh, E., \& Priyadi, M. P. (2016). Pengaruh Profitabilitas, Leverage, dan Ukuran Perusahaan terhadap Pengungkapan Tanggung Jawab Sosial Perusahaan. Jurnal Ilmu Dan Riset Akuntansi ISSN: 2460-0585, 5(10), 1-18.

Sugiyono. (2017). MetodePenelitian Kuantitatif, Kualitatif dan R\&D. Bandung: PT Alfabet. Sugiyono. (2017). MetodePenelitian Kuantitatif, Kualitatif Dan RED. Bandung: PT Alfabet.

Sumilat, H., \& Destriana, N. (2017). Faktor-Faktor Yang Mempengaruhi Pengungkapan Corporate Social Responsibility. Jurnal Analisa Akuntansi Dan Perpajakan, 1(2), 129-140. https:// doi.org/10.25139/jaap.v1i2.144

Susanto, Y. K. (2019). Corporate Social Responsibility Disclosure: Corporate Governance and Profitability. South East Asia Journal of Contemporary Business, Economics and Law, 20(1), 1.

Tan, A., Benni, D., \& Liani, W. (2016). Determinants of corporate social 
responsibility disclosure and investor reaction. International Journal of Economics and Financial Issues, 6(4), 11-17.

Thuy Anh, N., \& Tran, H. L. (2020). The determinants of corporate social responsibility disclosure: evidence from Vietnam's listed companies in chemical industry. Journal of International Economics and Management, 20(1), 18-41. https:// doi.org/10.38203/jiem.020.1.0002

Utamie, D. N., Akram, A., \& Nugraha Ardana Putra, I. N. (2020). Analisis FaktorFaktor yang Mempengaruhi CSR Disclosure Pada Perusahaan Manufaktur yang Terdaftar di BEI Periode 2016-2018. E-Jurnal Akuntansi, 30(1), 265. https://doi.org/10.24843/eja.2020.v30.i01.p20

Vijaya, D. P. (2009). Pengaruh Pengungkapan Tanggungjawab Sosial Perusahaan Terhadap Aktivitas Volume Perdagangan dan Harga Saham (Studi pada perusahaan yang terdaftar di Bursa Efek Indonesia). 1-24.

Wachira, M. (2017). Determinants of Corporate Social Disclosures in Kenya: A Longitudinal Study of Firms Listed on the Nairobi Securities Exchange. European Scientific Journal, ESJ, 13(11), 112. https:// doi.org/10.19044/esj.2017.v13n11p112

Wahyuningsih, A., \& Mahdar, N. M. (2019). Analisis Pengaruh Size, Profitabilitas Dan Leverage Terhadap Pengungkapan Csr Pada Perusahaan Yang Terdaftar Di Bursa Efek Indonesia. Journal of Chemical Information and Modeling, 53(9), 1689-1699. https://doi.org/10.1017/CBO9781107415324.004

Wang, J., Song, L., \& Yao, S. (2013). The determinants of corporate social responsibility disclosure: Evidence from China. Journal of Applied Business Research, 29(6), 1833-1847. https://doi.org/10.19030/jabr.v29i6.8220

Widyastari, N. K. W., \& Ratna Sari, M. M. (2018). Pengaruh Ukuran Perusahaan, Proporsi Dewan Komisaris Independen, dan Kepemilikan Asing pada Pengungkapan Corporate Social Responsibility. E-Jurnal Akuntansi, 22(3), 1826-1856. https://doi.org/10.24843/EJA.2018.v22.i03.p07

Wuttichindanon, S. (2017). Corporate social responsibility disclosure-choices of report and its determinants: Empirical evidence from firms listed on the Stock Exchange of Thailand. Kasetsart Journal of Social Sciences, 38(2), 156-162. https://doi.org/10.1016/j.kjss.2016.07.002 